\title{
A Brief Jacobsean Take on German Cities in Europe Through the Last Millennium
}

\author{
Peter J. Taylor
}

Published online: 21 May 2011

(C) Springer-Verlag 2011

The purpose of this Guest Editorial is to suggest a theoretically sound and empirically supported skeletal narrative for the place of German cities in the geohistory of Europe.

\section{Which First Geography of Cities in Europe?}

We have been bequeathed alternative stories from Max Weber and Henri Pirenne for the urban geography of medieval European cities. Weber's more political approach offered a historical global view contrasting the 'occidental' city where 'city air makes man free' to the 'oriental city' where this was not the case. His historical geography of Europe had city freedom concentrated north of the Alps with cities of southern Europe constituting a transition stage between the two types. In complete contrast, Pirenne focuses on the commercial revolution after $1000 \mathrm{AD}$ that was concentrated in northern Italy, with a second later commercial city growth in the Low Countries. It is this geography-Fernand Braudel calls it two poles of development - that Jane Jacobs used to develop her city theory of economic growth.

For the materialist approach that I take, I evaluate the importance of Weber's institutional freedom in terms of creating vibrant city economies: it is how the opportunities afforded by institutional freedom are harnessed to urban development that matters. This can be simply measured through city population estimates: for Jacobs, city success is measured in economic expansion that is reflected in urban population growth. In Table 1 cities are compared at the end of Europe's first great commercial revolution for both

Prof. P. J. Taylor $(\bowtie)$

School of Built and Natural Environment,

Northumbria University, Newcastle upon Tyne, NE1, 8ST, UK

e-mail: crogfam@yahoo.com
Table 1 Northern Italian and German cities in 1300

\begin{tabular}{llll}
\hline $\begin{array}{l}\text { Leading northern } \\
\text { Italian cities }\end{array}$ & Pop $(\mathrm{k})$ & $\begin{array}{l}\text { Leading German } \\
\text { cities }\end{array}$ & Pop $(\mathrm{k})$ \\
\hline Venice & 110 & Cologne & 54 \\
Genoa & 85 & Metz & 32 \\
Milan & 60 & Erfurt & 30 \\
Florence & 60 & Speyer & 30 \\
Bologna & 40 & Mainz & 24 \\
Padua & 39 & Lubeck & 22 \\
Cremona & 38 & Vienna & 21 \\
Verona & 36 & Aachen & 21 \\
Pavia & 30 & Worms & 20 \\
Pisa & 25 & Regensburg & 20 \\
Brescia & 24 & & \\
Ferrara & 23 & & \\
Piacenza & 23 & & \\
Siena & 21 & & \\
\hline
\end{tabular}

northern Italy and the vaster German lands north of the Alps. The contrast is stark: there are more and bigger cities in northern Italy despite their supposed half-way stage to being oriental cities.

\section{German Cities in the Modern World-System, 1500-1900}

Braudel describes an early modern movement of economic urban vibrancy from his Italian southern pole to the Low Countries northern pole. This idea has been developed by Immanuel Wallerstein into the theory of world hegemony in the sequence Amsterdam/Holland, London/Britain, and New York/USA. Thus it is with the coming of the modern world-system that northern Europe becomes economically predominant over southern Europe. This is reflected in success of its cities, but not always with German cities.

According to Jacobs successful cities are marked by 'explosive economic spurts' and 110 such have been iden- 
Table 2 Successful German cities in the modern world-system, $1500-1900$

\begin{tabular}{|c|c|c|}
\hline $\begin{array}{l}50 \text {-year } \\
\text { intervals }\end{array}$ & $\begin{array}{l}\text { Number of } \\
\text { economic spurts }\end{array}$ & $\begin{array}{l}\text { Economic spurts of German } \\
\text { cities }\end{array}$ \\
\hline $1500-1550$ & 12 & Augsburg, Magdeburg, Hamburg \\
\hline $1550-1600$ & 11 & NONE \\
\hline $1600-1650$ & 8 & NONE \\
\hline $1650-1700$ & 2 & NONE \\
\hline $1700-1750$ & 7 & NONE \\
\hline $1750-1800$ & 6 & NONE \\
\hline $1800-1850$ & 25 & $\begin{array}{l}\text { Munich, Leipzig, Hamburg, } \\
\text { Dresden }\end{array}$ \\
\hline $1850-1900$ & 39 & $\begin{array}{l}\text { Leipzig, Berlin, Dresden, } \\
\text { Hamburg, Munich, Ruhr }\end{array}$ \\
\hline
\end{tabular}

tified in the modern world-system from 1500 to 1900; German cases of these spurts are shown in Table 2.

The key point from the table is the unevenness of German city presences:

1. At the very beginning, before the spatial structure of the new system had been drawn by the Dutch, there are three eminently successful German cities but, being spread across German lands in the south, east and north, they do not define a city-cluster region such as found in the Low Countries.

2. After this there is a great void: for 250 years there are no recorded economic spurts in German lands.

3. But it is all change from 1800: German cities are very much part of the economic success story that is the industrialization of core-zones in the modern world-system.

In Wallerstein's hegemonic cycles, each hegemon state has an arch-rival that is defeated in a 'world war': the Hapsburgs in the Thirty Year War (1618-1648), France in the Revolutionary and Napoleonic Wars (1792-1815), and Germany in the twentieth century world wars (1914-1945). Focusing on the French and German challenges to Britain and the USA, the city-based analyses show very profound differences. In Table 3 the economic spurts of cities in both hegemonic and challenger states are listed during the initial rise phase of hegemonic cycles for the British (1700-1750) and the USA (1800-1850). There is a clear contrast between the lack of dynamic French cities to challenge British economic hegemony and the German challenge to the USA when German cities vied with US cities in their importance as economic spurts.

\section{The post-1900 Urban Rollercoaster}

In political economy terms Germany may have been the best-equipped hegemony-challenger but it still lost in the
Table 3 Comparing French and German challenges

\begin{tabular}{lllll}
\hline \multicolumn{2}{l}{ Rising British hegemony } & & \multicolumn{2}{l}{ Rising American hegemony } \\
\cline { 1 - 1 } Rank & Explosive city growths & & Rank & Explosive city growths \\
\hline 1 & Manchester & Liverpool & & Chicago \\
2 & Glasgow & & LEIPZIG \\
4 & Birmingham & & 4 & Pittsburgh \\
& NO FRENCH CITIES & & 6 & BERLIN \\
& FEATURE & 8 & DRESDEN \\
& & 9 & Boston \\
& & 11 & HAMBURG \\
& & 14 & MUNICH \\
& 22 & Philadelphia \\
& 25 & Baltimore \\
\hline
\end{tabular}

twentieth century world wars. The question then arises of what to do with such a formidable political-economy challenger? There were three positions: (i) retribution (Versailles in 1919 and the 1944 'Morgenthau Plan' for the 'pastorization of Germany'); (ii) rehabilitation (the Marshall Plan from 1947-1951); and the 'silent' repayment that is the European project (Jane Jacobs describes the failed empires of France and Britain 'milking' successful German cities). The current reluctance to bail out EU countries with cities less vibrant than Germany's suggests the rollercoaster has finally coming to a halt. This is reflected in the success of German cities in contemporary globalization. In Table 4 the latest results (2008) of world city network analysis illustrate the contrast between the 'horizontal' pattern of German cities compared with the primate patterns of France and the UK. In contrast to 'primate' France and Britain, in Germany, there are several cities with relatively good links, a diversity that should be advantageous in difficult times ahead for the global economy.

Table 4 French, German and UK cities in the top 100, 2008

\begin{tabular}{lll}
\hline Rank & City & GNC* \\
\hline 1 & London & 100.00 \\
4 & Paris & 78.24 \\
32 & Frankfurt & 50.03 \\
55 & Berlin & 39.29 \\
60 & Hamburg & 36.95 \\
67 & Munich & 34.78 \\
76 & Düsseldorf & 31.76 \\
91 & Stuttgart & 27.31 \\
\hline
\end{tabular}

* GNC is global network connectivity 